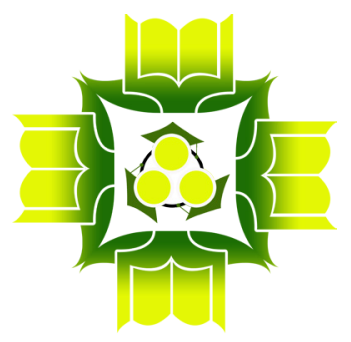

\title{
DIAGNOSTIC TEST PROFILE OF SCIENTIFIC LITERACY TO MEASURE STUDENT'S MISCONCEPTIONS IN SCIENCE CONCEPT COURSE
}

\author{
Siti Masfuah \\ Universitas Muria Kudus \\ siti.masfuah@umk.ac.id \\ Fina Fakhriyah \\ Universitas Muria Kudus \\ fina.fakhriyah@umk.ac.id \\ Insih Wilujeng \\ Universitas Negeri Yogyakarta, Indonesia \\ insih@uny.ac.id \\ Dadan Rosana \\ Universitas Negeri Yogyakarta, Indonesia \\ danrosana@uny.ac.id
}

\begin{abstract}
This study aims to develop diagnostic questions in measuring student misconceptions and to describe the profile of the misconceptions following students in the science concepts subject in the Motion Systems sub-chapter. This research is part of the research and development (R\&D) step in developing a four-level type of diagnostic test item consisting of a preliminary study stage, a development stage, and a validation stage. At this stage of development, the researcher gave open description questions to students of the Primary Educational Teacher Department, Universitas Muria Kudus in semester 3 of the 2018/2019 academic year classes 3C, 3D, 3E, and 3F to find the form of diagnostic questions, find answer options and options for these questions. The instrument is provided as a diagnostic question instrument in the form of a description. Based on data analysis, it is found that it is valid and reliable so that it can be used for research. The proportions of the resulting answers, namely there are four answer choices and four reason choices with
\end{abstract}


portions right, right with a little wrong, right with many wrong answers or reasons. Based on the results of the analysis of misconceptions, it is known that $23.7 \%$ of students answered correctly, $6,3 \%$ of students guessed the answer, $38 \%$ of students had misconceptions and $31.6 \%$ of students did not understand the concept.

Keywords: Diagnostic Test, Misconception, Scientific Literacy.

\begin{abstract}
Penelitian ini bertujuan untuk mengembangkan soal diagnostic dalam mengukur miskonsepsi mahasiswa dan mendeskripsikan profil miskonsepsi yang dialami mahasiswa pada mata kuliah konsep sains sub bab Sistem Gerak. Penelitian ini merupakan bagian dari langkah penelitian dan pengembangan $(R \& D)$ dalam mengembangkan soal tes diagnostic jenis four tier yang terdiri atas tahap studi pendahuluan, tahap pengembangan dan tahap validasi. Pada tahap pengembangan ini peneliti memberikan soal uraian terbuka kepada mahasiswa PGSD UMK semester 3 tahun ajaran 2018/2019 kelas 3C, 3D, 3E dan 3F untuk menemukan bentuk soal diagnostic, menemukan opsi jawaban dan opsi pilihan soal tersebut. Instrumen yang diberikan yaitu instrument soal diagnostic berbentuk uraian. Berdasarkan analisis data, diperoleh hasil bahwa soal bersifat valid dan reliable sehingga dapat digunakan untuk penelitian. Proporsi jawaban yang dihasilkan yaitu ada empat pilihan jawaban dan empat ilihan alasan dengan porsi benar, benar dengan sedikit salah, benar dengan banyak salah dan jawaban maupun alasan salah.Berdasarkan hasil analisis miskonsepsi, diketahui bahwa 23,7\% mahasiswa mejawab dengan benar, 6,3\% mahasiswa menebak jawaban, 38,\% mahasiswa mengalami miskonsepsi dan 31,6\% mahasiswa tidak paham konsep.
\end{abstract}

Kata Kunci: Soal Diagnostik, Miskonsepsi, Literasi Sains.

\title{
INTRODUCTION
}

Education provides a large contribution to the progress of a country. The development of a country is determined by the progress of education in that country (Nowak 2016, 22). One of the determining factors for the success of such education is the teacher. The teacher as the director has the task of developing learning scenarios that direct students to think and do so that students' competencies and potentials can develop optimally. Important competencies students must possess include scientific literacy because this ability can influence the way decisions are made in solving problems (Lederman et al. 2013, 138). Scientific literacy is the ability to understand science, and implement science in daily life that involves the ability to think at a higher level, and scientific attitudes, 
social attitudes integrated with various disciplines (Holbrook \& Rannikmae $2009,277)$. Science literacy is very important because it not only uses science as knowledge but involves processes and attitudes to implement science in everyday life. Therefore, scientific literacy is of particular concern to countries in the world, especially members of the OECD (Economic Cooperation and Development), including Indonesia.

However, Indonesian students have low scientific literacy achievements. Based on the 2015 OECD (2016), it was found that Indonesia's achievements ranked 62 out of 72 countries with an average score of 395. Despite the increase, the score was still concerning compared to countries in others Asia. This shows that scientific literacy competencies need special attention. The low achievement of scientific literacy in Indonesia is influenced by many factors, including the readiness of students and teachers. Students are not accustomed to working on Higher Order Thinking Skills (HOTS) which contain indicators of scientific literacy. One reason is because the teacher only gives questions to the realm of thinking memory and knowledge. Therefore, the teacher must familiarize students with practicing scientific literacy skills through HOTS questions. Wulandari \& Raekha $(2018,37)$ argued that the habit of giving HOTS questions could prepare Indonesian students in facing PISA literacy assessment.

Universitas Muria Kudus Primary Educational Teacher Department (PGSD UMK) as an Educational Personnel Education Institution (LPTK), is also responsible for elementary school teacher graduates. Therefore, the pre-service teacher must be given provision to produce quality students with good scientific literacy skills. The quality of a teacher is determined by many factors, including teacher competence pedagogy. Teachers must be able to think with higher-order thinking skills and have skills so that the scientific literacy competencies possessed can be well-honed. But in reality, the scientific literacy ability of PGSD students is not good. 66.2\% of students are at the nominal level (Fakhriyah et al. 2017, 83). Actually, students have been able to show a solution but only just memorized without a more detailed explanation of that solution step.

After the initial assessment of scientific literacy skills, students are then given textbooks based on scientific literacy so that their scientific literacy competencies increase. Based on the readability test, the book is easy to understand (Fakhriyah et al. 2018, 167). Thus, students are able to understand the contents of books and carry out learning properly in accordance with scientific literacy competencies. 
Furthermore, students are given a computational thinking test to assess deeper their scientific literacy competencies. The reason for this CT test is because CT is a renewable literacy in the 21st century (Mohaghegh \& Michael 2016, 1526). CT and scientific literacy are competencies used to solve problems. The ability of scientific literacy can be improved through CT competence and vice versa, the ability of CT contributes to scientific literacy (Jacob \& Warschauer 2018, 3). Thus, if the CT competency of students is good, then the achievement of students' scientific literacy is also good. Based on the results of CT tests totaling 16 questions given, the CT ability of students is at the stage of finding a solution and has not been able to go to the algorithmic stage. Algorithms are one's ability to solve problems coherently and systematically (Wing 2006, 34). Based on these results it is known that there are errors in the understanding of students because they understand the solution but cannot explain in detail by involving various disciplines. To ensure the students' misconceptions, they are given a questionnaire that contains the response to the reasons for the misconceptions that they have and the reasons that might be the cause for them not understanding the concept. Based on these data, it turns out students have three categories, namely $28.6 \%$ in the category of not understanding the concept, $33.3 \%$ in the category of missing concepts and $38.1 \%$ in the category of misconceptions (Masfuah \& Fakhriyah 2019, 4). Thus, most students experience misconceptions.

Misconception is students' understanding of a concept that cannot be accepted scientifically (Anam 2018, 3233). This misconception is a concept that is understood by someone but the concept is wrong according to the theory of experts. If left unchecked, this misconception can hinder students' achievement (Keshavarz et al. 2017, 78).

This misconception is caused by many factors, including textbooks, teacher factors, environment, scientific language, and students' initial concepts (Chrzanowski 2018, 29; Oberoi 2017, 6274; Lin et al. 2016, 2621; Schmidt 2011, 441). If the concepts received by students are not in accordance with the concepts according to the experts, then many things happen that the students experience missing concepts (concepts that cannot be perfectly accepted) or experience misconceptions (Aufschnaiter \& Christian 2010, 12). This misconception can reduce student achievement. If students as prospective elementary school teachers experience misconceptions, elementary students will not have good performance. Therefore, diagnostic test questions are needed to measure 
students' misconceptions, where the questions contain indicators of scientific literacy, because students may understand the concepts of science but have difficulty understanding scientific problems. In addition to measuring the level of understanding of student concepts, this problem also measures misconceptions about science literacy questions.

Measurement of student misconceptions can be done by a variety of methods, including multiple-choice questions, concept maps, description questions and graded questions (Gurel et al. 2015, 992; Rusilowati 2015, 4; Nurlaila et al. 2018, 43). In this study, the diagnostic questions developed are four-tier diagnostic tests where this question is a four-level question consisting of answer choices, level of confidence in answering, choice of reasons and level of confidence in answering reasons. In contrast to diagnostic test in general, the development of science literacy diagnostic tests is not necessarily made by the lecturer, but the content of the questions, choice of answers and choice of reasons are derived from students' thinking. Thus, the diagnostic problem is more valid in measuring student misconceptions. Therefore, the development of this science-lined diagnostic problem is very important because it can identify the location of misconceptions experienced by students, lecturers can find material difficulties that are not understood by students so that they can be used to improve subsequent learning.

\section{METHODS}

This research is part of a research and development (R\&D) that aims to develop a diagnostic test of the four-tier diagnostic test in measuring student misconceptions. The developmental research steps undertaken are the preliminary study stage, the development stage and the validation stage (Samsudi 2006, 74). In the preliminary study stage based on the computational thinking (CT) test given, it is known that the CT ability of students is at the level of the algorithm, in fact students are able to provide answers but have not been able to explain in detail. After that, students are given a questionnaire to find out whether students experience misconceptions or not based on the answers to these questions. The results of the questionnaire showed that there were three clusters of understanding in students namely the misconception cluster, the cluster missing concept and the cluster not understanding the concept (Masfuah \& Fakhriyah 2019, 4). Based on these results, it is diagnosed if a student experiences a misconception so that the development of this diagnostic problem is needed. The results of the 
questionnaire also stated that students did not understand the concept of the Motion System material, so researchers developed this diagnostic problem on the Motion System material.

Furthermore, the diagnostic test type four-tier diagnostic test was chosen because this type of question is able to reveal more detailed misconceptions because each answer given has a level of confidence (Gurel et al. 2015, 1001). To find the proportion of the four-tier diagnostic test, students are given a matter of description to find the form of questions, choice of answers and choice of reasons. So, the choice of answers and reasons is based on understanding and concepts known to students.

The instrument used was an open description question that had to be answered and accompanied by reasons given to students of PGSD UMK class 3C, 3D, 3E, and 3F in the academic year 2019/2020, amounting to 102 students. Students must provide answers and reasons that they think are right and are accompanied by a level of confidence in answering and reasoning, the level of confidence that is sure (1) and not sure (0). The answers and reasons from the students are then analyzed quantitatively and qualitatively.

The quantitative analysis aims to analyze reliability, distinguishing features and difficulty levels of questions, and analyze misconceptions experienced by students. While qualitative analysis is used to find the answer choices and choice of reasons in the four-tier diagnostic tests that were developed. Misconceptions experienced by students can be identified by the Certainty of Response Index (CRI) technique (Hasan et al. 1999, 296). This technique helps map student misconceptions by comparing answers with the level of confidence of the answers (CRI scores). Categories of student CRI answers and beliefs can be seen in Table 1.

Table 1. Misconception Category Based on CRI's Answer and Confidence Level

\begin{tabular}{ccc}
\hline Answered & CRI Low (0) (Not sure) & CRI High (1) (Sure) \\
\hline Right & guessing & Understand the concept \\
False & Do not understand concept & Misconception \\
\hline
\end{tabular}

\section{RESULTS AND DISCUSSION}

The development stage of this research is part of the research and development (R\&D) consisting of a preliminary study phase, a development 
phase and a validation stage based on Samsudi's theory $(2006,74)$. This study aims to develop a four-tier diagnostic test diagnostic type, which consists of four levels, namely the choice of answers, the level of confidence of the answers, choice of reasons and the level of reasoning confidence.

The topic of material in this diagnostic problem is the Motion System because based on the results of the questionnaire and student learning outcomes it is known that students have difficulty with this material. These difficulties are known based on the preliminary study stage carried out by providing CT test questions. The results of the questions are then analyzed based on true or false answers. Furthermore, students are given a questionnaire containing the reasons and possible causes of misconceptions. The results of the questionnaire showed that there were three clusters of concepts understanding in students namely the concept understanding cluster, the cluster missing concept and the cluster concept. Based on a questionnaire analysis, it is known that $38.1 \%$ of students experience misconceptions (Masfuah \& Fakhriyah 2019, 4).

Furthermore, at this stage of development, the researcher develops a diagnostic test type four-tier diagnostic test because this type of question does not only contain answers but also contains reasons and levels of confidence in answering and reasoning so that more valid results are obtained (Suparno 2013). The choice of answers and reasons for the problem are obtained from the answers that are considered correct by students. Therefore, to find the answers and reasons, at this stage of development, students are given a matter of description and reasons on the Motion System material. The material consists of a system of motion in low-level living things, a motion system in animals, a motion system in plants, a motion system in humans, motion in objects, forces and effects and Newton's laws.

Before given the test, the researcher made a grid and the questions consisting of 40 questions. This questions are not just an ordinary diagnostic test but a diagnostic test of scientific literacy which contains aspect of scientific literacy, which consists of scientific content, competencies and scientific context based on aspects of scientific literacy from PISA (Holbrook \& Rannikmae 2009, 279). Students are free to give answers and reasons that they think are correct. The answers and reasons are then analyzed qualitatively to find the choice of answers and choice of reasons in the four-tier diagnostic test developed. 
The results of the answers and reasons from the students are listed, categorized and chosen with the criteria of perfect right, right with a little wrong, right with lots of wrong and wrong. The choice of deceptive answers given, are categorized according to understanding errors, unit conversion errors, calculation errors, comparability errors, formula errors, or graph/data interpretation errors. So, the choice of answers and reasons consists of four choices consisting of one correct choice and 3 wrong choices. The choice of answers and reasons are found from the most answers of students. The finding answers and such reasons are derived from students' thoughts so that the average student will answer like that too. Because all choices of answers and reasons come from students 'minds and understanding, it will really measure students' understanding of concepts so that more valid results are obtained.

In addition to finding the form of this four-tier diagnostic test, this development stage also analyzed the items to measure reliability, differentiation, and difficulty of the questions. Based on the analysis of the items it is known that the questions are reliable so they can be used for research. This item analysis consists of analysis of reliability, level of difficulty and distinguishing features of the problem. The results of the item analysis can be seen in Table 2.

Reliability analysis using the Alpha Cronbach formula, the power of distinguishing questions by using the proportion of students who answered right and wrong answers, the level of difficulty of the questions by comparing the correct answers with the total score obtained. The results of the item analysis of the questions can be seen in Table 2.

Table 2. Item Analysis Test

\begin{tabular}{cccc}
\hline No & Analysis & Result & Criteria \\
\hline \multirow{2}{*}{1.} & Reliability & $\mathrm{t}_{\text {hitung }}=0,899$ & \\
& & $\mathrm{t}_{\text {table }}=0,193$ & reliabel \\
& & 9 item & Throw \\
& & 19 item & Fix it \\
2. & Distinguishing Power & 9 item & Accept \\
& & 3 item & Can used \\
& & 17 item & Hard \\
3. & Difficulty level & 23 item & Medium \\
& & 0 item & Easy \\
\hline
\end{tabular}


Based on Table 2, there are several problems that need to be fixed. The results of the questions and answers from the students are then consulted with the Partner Research Team (TPM) to be given input based on the question construction, answer construction and the reasons that have been formed. Previously, this instrument was validated by 7 experts and obtained very valid criteria so that it can be used for research (Masfuah et al. 2021, 687). In addition to analyzing the items, this development stage can also measure the profile of misconceptions experienced by students. Instruction questions given are students must answer and reasoning accompanied by their level of confidence in answering. If they are sure, it is worth 1 , if you are not sure it is 0 . Then the answer from the student is then analyzed using the CRI technique, which is to compare the answers and the level of confidence of reasons such as Table 1. The profile of students' understanding is divided into understanding, guessing, misconception and not understanding. Profile of student misconceptions in this study can be seen in Graph 1.

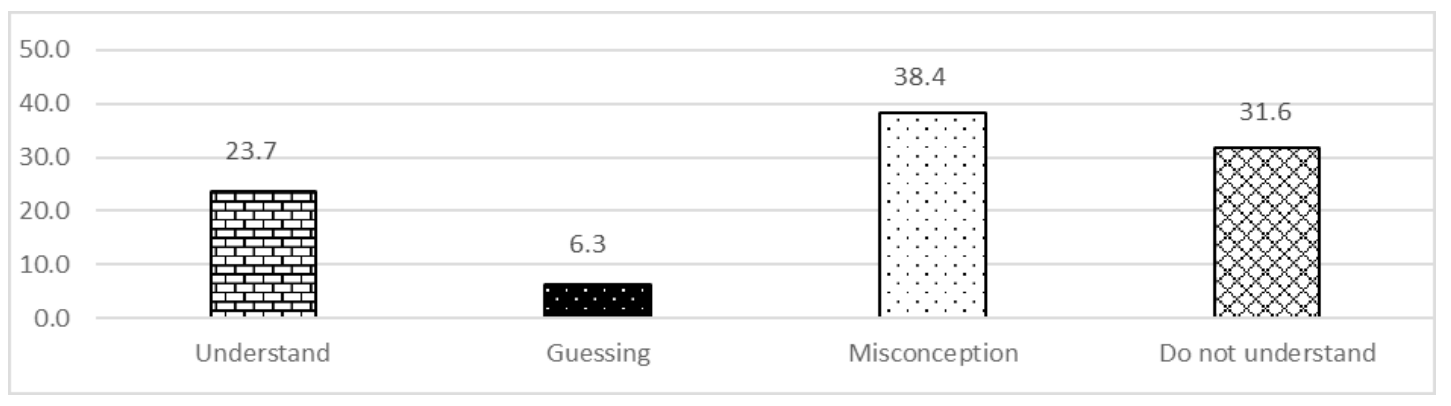

Graph 1. Profile of Student Misconceptions

Graph 1 show that $38.4 \%$ of students experienced misconceptions, 31.6\% of students did not understand the concept, $23.7 \%$ of students understood the concept, while $6.3 \%$ of students guessed the answer. The student misconception profile was obtained based on 40 description questions accompanied by a level of confidence in answering physics and biology material questions. This question is divided according to the topic of the material so that it is easy to detect any misconceptions (Fakhriyah \& Masfuah 2021, 5). Based on these data, the level of student misconceptions is greater than students who understand the concept. The biggest misconception experienced by students lies in the aspects of knowledge and the context of science (Udompong \& Suwimon 2014, 5091). That happened because the scientific background of PGSD students came from various majors. Based on the results of the questionnaire, the majority of students came from 
social majors. There are also students who come from vocational schools, and a few who come from majors (Fakhriyah et al. 2017, 84). Based on previous research, students' scientific literacy is at the nominal level (Fakhriyah et al. 2017, 83). The student's scientific literacy achievements are in sync with the results of diagnostic tests conducted. Thus, the cause of the low achievement of students' scientific literacy is due to their misconceptions. Even though $43 \%$ are at level 5 in complex arguments, i.e. able to argue with more than one rebuttal (Fakhriyah \& Masfuah 2021, 4).

In addition, science is one of the subjects that students dislike because science involves abstract concepts, must use logic and calculations to understand them, using various scientific terms and mathematical formulas. The use of scientific language can cause student misconceptions (Chrzanowski et al. 2018, 29).

The results also showed that only $23.7 \%$ of students understood the concept. These results will be evaluated by lecturers to improve further learning. The results of the student misconception profile in Graph 1 are calculated globally, while the profile of student misconceptions based on physics and biology question categories can be seen in Graph 2.

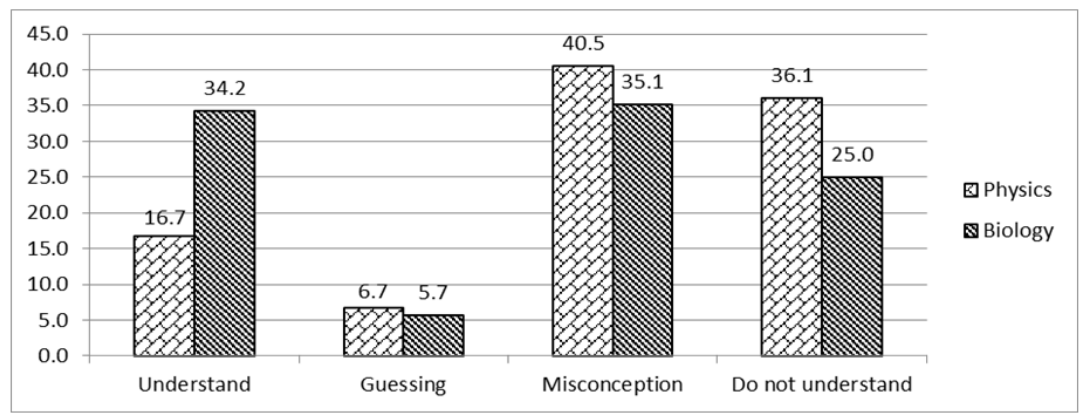

Graph 2. Profile of Student Misconceptions on Motion System Material

Graph 2 shows that there are more misconceptions about physics matter than biology misconceptions. That is because physics matter involves abstract concepts, imagination, the law of causes and effects of the phenomenon in the universe. They must use logic and analogies to understand concepts. Abstract concepts can be understood through incur learning and balancing aspects of knowledge and processes in learning so as to remind students of scientific literacy 
(Lederman et al. 2013, 144).

In addition to abstract concepts, physics material involves a lot of mathematical formulation, calculations, use of formulas, comparisons that require students to use logic more and think more complex when compared to biology material. Calculations, formulas, graphs and mathematical concepts are closely related to physics. That is the difficulty of students in learning physics. Research conducted by Kapasa et al $(2015,145)$ and Mulwa $(2015,27)$ found that many students had basic mathematical abilities that were lacking.

The level of understanding of students in biology material is also better than their understanding of physics material. That is because biology learns about plants, animals, and humans that are commonly found in daily life, closer to them, as if studying themselves. In this problem, the material discussed is motion. When compared to motion in physics, motion in biology is easier to understand because they are analogous to one self. Besides that, the material is more concrete so that students can understand it more easily. The use of concrete media in learning will make learning more effective (Rusiman \& Norziha 2017, 2174)

To get a profile of the misconceptions experienced in biology material, researchers examined the results based on the sub-material being tested, namely motion in low-level living things, motion in plants, motion in animals and motion in humans. Profile of misconceptions of biology material can be seen in Graph 3.

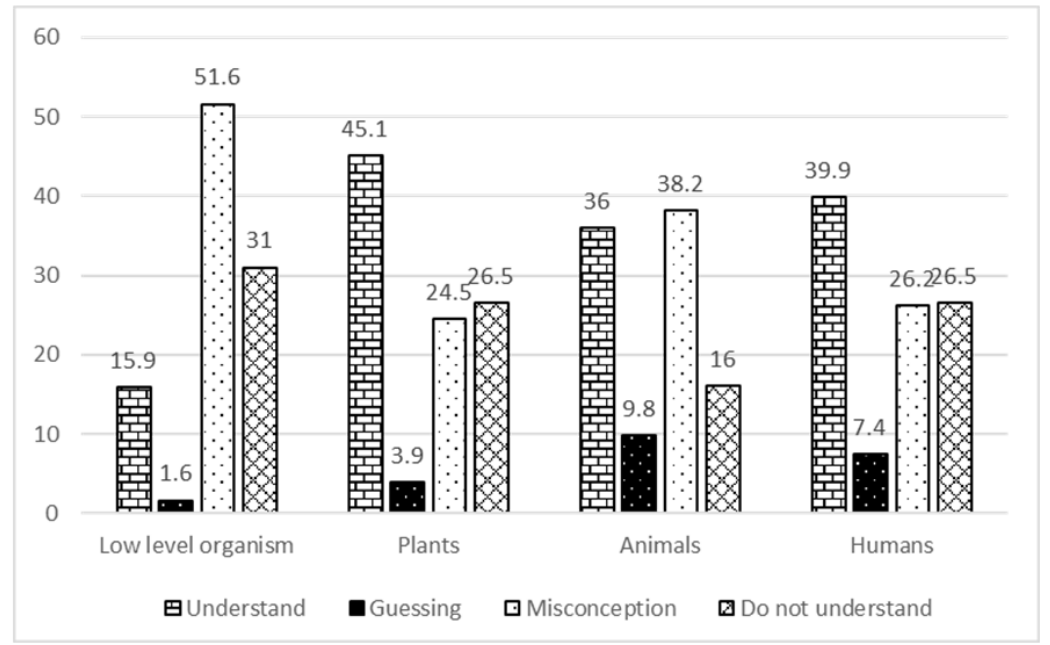

Graph 3. Profile of Biology Misconceptions 
Graph 3 shows that the highest level of misconception experienced by students is in the sub-material of motion in low-level living things, namely $51.6 \%$, $31 \%$ do not understand the concept, $15.9 \%$ are able to understand the concept and $1.6 \%$ guess the answer. The movements in low-level organism creatures that were tested included movements in Eubacteria, Archaebacteria, Protista, and Fungi. Before students identify about motion, they must first classify these living things into which kingdom. Difficulties in this classification can cause student misconceptions. Yangin et al. $(2014,105)$ analyzed that the classification of living things contributed to misconceptions.

Motion in low-level organism creatures is difficult to understand because it cannot be seen directly. In understanding the material, students must use logic and imagination because the concept of motion is abstract. The explanation of the material must be through laboratory activities. However, the science laboratory owned by the study program is only a laboratory for the production of science media and the intensity of the laboratory is smaller because of the limitations of the lab. In fact, Duban et al. $(2019,772)$ argued that laboratory and open-ended activities would make them more active in learning and solving problems. Teaching activities by way of practice and visual material can facilitate students in learning biology (Cimer 2012, 61).

The second material is about motion in plants. As many as $45.1 \%$ were able to understand the concept well, 3.9\% guessed the answer, $24.5 \%$ experienced misconceptions and 26.5 did not understand the concept. Although there are students who experience misconceptions, $45.1 \%$ are able to understand the concept. This happens because the concept of motion in plants can still be identified and analyzed even though the process is difficult to experience directly. In this concept, students are able to analyze the motion in plants through the phenomena they encounter in daily life. For example, the motion of tropism can be seen from the direction of the window-moving plants that move towards the sun, the motion of nasti can be seen from the embarrased princess who is easily found. This material is not too complex, as long as students are able to analyze the concepts of motion and existing phenomena, they are able to understand this material.

The next sub material is the concept of motion in animals. At this material $38.2 \%$ of students experienced misconceptions, $16 \%$ did not understand the concept, $9.8 \%$ guessed the answer and $36 \%$ were able to understand the concept well. The material of this animal movement also causes misconceptions. Thompson 
\& Logue $(2006,554)$ based on the results of their research explained that students assume animals are multicellular organisms that can move independently so that mammals and vertebrates are animals while invertebrates are not animals.

Based on Graph 3, the comparison of students who understand the concept with students who experience misconceptions is almost the same. The motion system of this material in the category is still simple because it only identifies the means of motion in the animal, but students must be able to analyze parts of the vertebrate and invertebrate animal motion systems. If they only identify the type of motion tool, they are able to answer well, but if they have to analyze the parts of the motion device and the process, they have difficulty and experience misconceptions. For example, the way Asteroida moves. They were able to mention if Asteroids was able to move with the ambulacral system, but they were not able to analyze the ambulacral foot process so that it was able to inflate and deflate and other functions. They assume that the material has nothing to do with his life so it is considered not important. In addition, explanations and the process of moving in invertebrate animals involve abstract concepts that are difficult to understand. Etobro \& Fabinu $(2017,145)$ explained that abstract and complex concepts will cause misconceptions on biological material.

Furthermore, in the sub-chapter of the concept of motion in humans, 39.9\% of students were able to understand the concept well, $7.4 \%$ guessed the answers, $26.2 \%$ experienced misconceptions and $26.5 \%$ were unable to understand the concept. Although $26.2 \%$ of students experienced misconceptions, $39.9 \%$ of students were able to understand the concept well. That is because they seem to see themselves in understanding this material. This concept is concrete, they can feel, they can analyze without having to imagine. Learning science that is not real will make students difficult to study science, on the contrary, concrete material and its relationship with daily life can make it easier for students to learn science concepts (Osuolale 2015, 115)

At this material, the misconceptions experienced by students are related to the implementation of the concept of motion in daily life, for example, the use of steroids in body builder athletes to accelerate muscle mass enlargement. Students must be able to analyze and evaluate activities that are able to maintain our motion systems properly, take wise steps without having to use instant methods that are at high risk to get their desires. The next material is the process of osteoporosis. If they only answer the factors that cause osteoporosis, they are 
able to answer well, but if asked to analyze how the process occurs until the bone is porous, they are difficult to answer.

The given physics material is Irregular Rectilinear Motion (RM), Accelerated Linear Motion (ALM), Circular Motion (CM), Projectile Motion (PM), and Newton's Law (NL). Profile of student misconceptions on physics material can be seen in Graph 4.

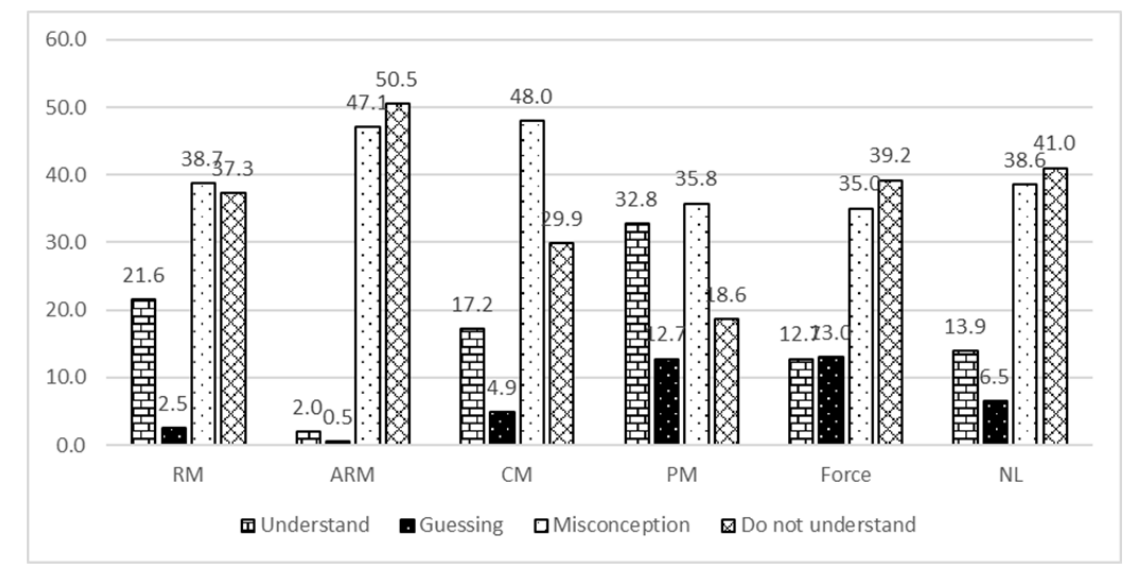

Graph 4. Profile of Physics Misconceptions

Graph 4 shows that misconceptions on the material of rectilinear motion by $38.7 \%$, understanding concepts by $21.6 \%$, guessing by $2.5 \%$, while those who do not understand concepts by $37.3 \%$. In the concept of rectilinear motion, students experience a misconception in the concept of distance and displacement because it involves a vector, while students ignore the displacement vector. Students also wrongly analyzed between average velocity and instantaneous velocity on the application of the motion. Many students experience misconceptions about the concept of kinematics because students have difficulty defining the concepts of displacement, distance, velocity the concept of 0 on the graph (Motlhabane 2016, 439).

At the concept of uniformly accelerated linear motion, $47.1 \%$ of students experience misconceptions, $50.5 \%$ do not understand the concept, understand the concept by $2 \%$ while guessing by $0.5 \%$. Misconceptions experienced in this material are misinterpretations of the velocity and acceleration experienced by the same two objects and the interpretation of velocity and acceleration in the interpretation of graphs in motion with deceleration, the concept of vertical 
upward motion, and how to find the two objects meet with differences in speed through a graph. Interpretation of graphs and diagrams is the factor that contributes the most to this misconception. Many students argue that if two objects have the same velocity then objects have the same acceleration, many students do not understand the negative acceleration (Liu \& Ning 2016, 24).

It is in the concept of circular motion that the biggest misconception experienced by students is $48 \%$, both rectilinear motion and uniformly accelerated rectilinear motion. The material is difficult to understand because the acceleration and force experienced in objects that move in a circle are different from objects that move in a straight line. In this material, the misconceptions are the concept of equilibrium of the circular motion force in the game of devil casks, factors that cause the devil cask players to be able to move in a circle without falling, centripetal force and centrifugal force in everyday life, the concept of circular motion in roller coaster games. This material experiences a lot of misconceptions because the concept of circular motion must take into account the magnitude of the radians, centripetal velocity as well as centripetal acceleration and force direction. This is in accordance with research conducted by (Danika et al. 2017, 295) which found that there was a misconception in the material concept of rotational motion because they ignored the position vector in answering and assumed the same between rotational motion and translational motion). In this concept, they also have to take into account the rules of sine, cosines, and tangent because it involves motion with radians coordinates. Many students ignore the acceleration of an object when the object has a different velocity direction (Liu \& Ning 2016, 24). Difficulties in computation and comparability also contribute to the misconceptions experienced by students in this material.

In parabolic motion material, $35.8 \%$ of students experienced misconceptions, $18.6 \%$ did not understand concepts, $32.8 \%$ understood concepts and $12.7 \%$ guessed answers. The misconceptions experienced by students on this material are the concept of motion on the vertical point and horizontal path. Students wrongly analyze the speed that moves on the $\mathrm{X}$-axis and the large speed that moves on the $\mathrm{Y}$-axis causing the object to fall at its highest position. They understand that gravity is the only reason why objects fall/move down, without looking at the velocity vector of each direction. In addition, students do not take into account the influence of the elevation angle on this motion. Because students experience a lot of misconceptions, there is RM and ARM material on both straight and circular 
paths, it also contributes to the material of parabolic motion. So, the initial concept received by students contributes to the formation of the next material concept, so that if the student's previous material experiences misconceptions, then in this material they also experience misconceptions (Aufschnaiter \& Christian 2010, 279). Therefore, the magnitude of misconceptions experienced by students on this material is also quite large. In addition, this material involves translational and rotational motion, including free-fall at the highest point. Students have not been able to analyze this concept of motion on the X-axis and Y-axis therefore they assume that when at the highest point, object have no speed and are only influenced by the force of gravity, without taking into account the speed on the X-axis. Montecinos $(2014,6)$ gets the results that students understand about the concept of free fall motion but they do not understand the magnitude of the acceleration and influence of forces at each of these motion points.

In this force concept, 35\% of students experience misconceptions, 39.2\% do not understand the concept, $12.7 \%$ understand the concept, while $13 \%$ guess the answer. In this material, students had misconceptions about the concepts of mass and weight, the application of frictional forces to objects, the influence of forces on objects, the principle of equilibrium forces, the principle of forces that cause acceleration, the application of forces on a system. Unit conversion errors, the mathematical formulation of questions into the form of formulas, image interpretation, comparative formulas, and calculation errors become factors that contribute to the misconceptions experienced by students. Some misconceptions experienced by students on force material according to research from Fadaei \& Cesar $(2015,43)$ are factors that will determine motion, forces acting on objects must cause objects to move, forces will cause acceleration, gravitational acceleration is influenced by mass and obstacles air.

The last sub material tested is Newton's Law. In this material 38.6\% of students experienced misconceptions, $41 \%$ did not understand the concept, $13.9 \%$ of students were able to understand this concept and $6.5 \%$ of students guessed the answers. Errors in Newton's law include if the net force acting on an object is zero, then the object will be stationary, but if the total force acting is not equal to zero, then the object will move constantly. This is consistent with the results of the research (Smith \& Banilower 2006, 11). Newton's Law Material II made the biggest contribution to the misconceptions experienced by students. That happens because, in the concept of RM, ARM and force, students 
have experienced a conception. The initial concept of the student contributes to the formation of the next concept. If students have experienced misconceptions about prerequisite material, the next material will also experience misconceptions (Anam 2018, 3326).

\section{CONCLUSION}

Based on data analysis and discussion, it is known that the four-tier diagnostic test developed to consist of four answer choices, the level of confidence in answering, four choices of reasons and the level of confidence of the reasons obtained from the results of student answers based on open-ended questions. The question is analyzed by the item to get a valid problem. Based on the analysis of misconceptions by the CRI method, obtained the profile of misconceptions experienced by students on the material of the motion system that is known that $23.7 \%$ of students answered correctly, $6.3 \%$ of students guessed the answer, $38 . \%$ of students experienced misconceptions and $31.6 \%$ of students did not understand the concept. Students experience many misconceptions about physics material, rather than biology material, especially in the sub-circular motion material. 


\section{REFERENCES}

Anam, I. M. S. (2018). Exploring Teachers's Understanding about Misconceptions of Secondary Grade Chemistry Students. International Journal for CrossDisciplinary Subjects in Education (IJCDSE), 9(1), 3323-3328. DOI:10.20533/ ijcdse.2042.6364.2018.0444

Aufschnaiter, C., V. and Christian, R. (2010). Misconceptions or Missing Conceptions?. Eurasia Journal Mathematics, Science and Technology Education, 6(1), 3-18. DOI:https:// doi.org/10.12973/ ejmste/75223

Chrzanowski, M.M., Grajkowski, W., Zuchowski, S, Spalik, K., \& Ostrowska, E., B. (2018). Vernacular Misconception in Teaching Science-Types and Causes. Journal of Turkish Science Education, 15(4), 29-54. DOI: http:// dx.doi.org/10.12973/tused.10244a

Cimer, A. (2012). What Makes Biology Learning Difficult and Effective: Students' Views. Educational Research and Reviews, 7(3): 61-71. DOI: 10.5897/ ERR11.205

Danika, P, O., Yuliati, L. \& Wartono. (2017). Concept Acquisition of Rational Dynamics by Interactive Demonstration and Free-Body Diagram. Journal of Education and Learning, 11(3): 291-298. DOI: http://dx.doi. org/10.11591/edulearn.v11i3.6410

Duban, N., Aydogdu, B., \& Ash, Y. (2019). Classroom Teachers' Opinions on Science Laboratory Practices. Universal Journal of Educational Research, 7(3): 772-780. DOI: 10.13189/ujer.2019.070317

Etobro, A., B. \& O., E., Fabinu. (2017). Students; Perceptions of Difficult Concepts in Biology in Senior Secondary Schools in Lagos States. Global Journal of Educational Research, 16: 139-147. DOI: http:/ / dx.doi.org/10.4314/gjedr. v16i2.8

Fadaei, A., S. \& Mora, C. (2015). An Investigation About Misconception in Force and Motion in High School. US-China Education Review A, 5(1): 38-45. DOI: 10.17265/2161-623X/2015.01.004

Fakhriyah, F., \& Masfuah, S. (2021). The analysis of scientific argumentation skill and computational thinking skill of the primary educational teacher 
department students. AIP Conference Proceedings, 2331. https://doi. org/10.1063/5.0041655

Fakhriyah, F., \& Masfuah, S. (2021). The Development of a Four Tier-Based Diagnostic Test Diagnostic Assessment on Science Concept Course. Journal of Physics: Conference Series, 1842(1), 0-8. https:/ / doi.org/10.1088/17426596/1842/1/012069

Fakhriyah, F., Masfuah, S., Roysa, M., Rusilowati, A., Rahayu, E. S. (2017). Student's Science Literacy in The Aspect of Content Science?. Jurnal Pendidikan IPA Indonesia, 6(1): 81-87. DOI: https://doi.org/10.15294/jpii. $\underline{\mathrm{v} 6 \mathrm{i1}}$

Fakhriyah, F., S. Masfuah, \& M. Roysa. (2018). Readability of Conceptual Science Material Teaching based on Science Literacy Using Modified Cloze Test Technique to Develop Computational Thinking Skills. Proceeding Advances in Social Science, Education and Humaniities Research. Volume 262. DOI: https://doi.org/10.2991/ictte-18.2018.29

Gurel, D., K., A. Eryilmaz, \& L., C., McDermott. (2015). A Review and Comparison of Diagnostic Instruments to Identify Students' Misconception in Science. Eurasia Journal of Mathematics, Science \& Technology Education, 11(5): 9891008. DOI: 10.12973/Eurasia.2015.1369a

Hasan S., Diola, B. \& Ella, L. K. (1999). Misconceptions and the Certainty of Response Index (CRI). Phys.Educ, 34(5): 294-299. DOI: 10.1088/0031$9120 / 34 / 5 / 304$

Holbrook, J., \& Rannikmae, M. (2009). The Meaning of Scientific Literacy. International Journal of Environtmental \& Science Education, 4 (3), 275-288. DOI: 10.1088/0031-9120/34/5/304

Jacob, S. R. \& Warschauer. M. (2018). Computational Thinking and Literacy. Journal of Computer Science Integration, 1(1): 1-19. DOI: https://doi. org/10.26716/jcsi.2018.01.1.1

Jeannette M. Wing. (2006). Computational thinking. COMMUNICATIONS OF THE ACM, 49(3), 33. https:/ / doi.org/10.1145/1999747.1999811 
Kapasa, J., Elizabeth, B., S., \& Peter, J., M. (2015). Problems Faced by Students and Lecturers in Teaching and Learning of Approximation in Primary Colleges of Education: A Case Study of 4 Primary Colleges on the Copperbelt Province- Zambia. Journal of Education and Practice, 6(17): 146. https:/ / www.iiste.org/Journals/index.php/JEP/article/view/23600

Keshavarz, E., Aferef, A., \& Rana, A. (2017). High School Students' Idea about Concepts Related to Chemistry and Physics: An Exploration of Common Misconception in Science. Journal of Research $\mathcal{E}$ Method in Education (IOSRJRME), 7(5): 71-74. DOI: 10.9790/7388-0705027174

Lederman, N.G, Lederman, J.S., \& Antink, A. (2013). Nature of Science and Scientific Inquiry as Contexts for the Learning of Scinece and Achievement of Scientific Literacy. International Journal of Education in Mathematics, Science and Technolgy, 1(3): 138-147.

Lin, J. W., Yen, M. H., Liang, J. C., Chiu, M. H., \& Guo, C. J. (2016). Examining the Factors that Influence Students' Science Learning Processes and Their Learning Outcomes: 30 Year of Conceptual Change Research. Eurasia Journal of Mathematics, Science \& Technology Education, 12(9), 2617-2646. DOI: 10.12973/eurasia.2016.000600a

Liu, G. \& Ning, F. (2016). Student Misconceptions about Force and Acceleration in Physics and Engineering Mechanics Education. International Journal of Engineering Education, 32(1A): 19-29. https:/ / www.researchgate.net/ publication/295010239

Masfuah, S., \& Fakhriyah, F. (2019). Misconception Analysis Based on Feedback of Computational Thinking Result of College Students. Journal of Physics: Conference Series, 1397(1). https://doi.org/10.1088/17426596/1397/1/012021

Masfuah, S., Fakhriyah, F., Wilujeng, I., \& Rosana, D. (2021). The Content Validity of Scientific Literacy-Based Diagnostic Assessment. Proceedings of the 7th International Conference on Research, Implementation, and Education of Mathematics and Sciences (ICRIEMS 2020), 528(Icriems 2020), 684-691. https://doi.org/10.2991/assehr.k.210305.099 
Mohaghegh, M., \& Michael, McCauley. (2016). Computational Thinking: The Skill Set of the $21^{\text {st }}$ Century. International Journal of Computer Science and Information Technologies, 7(3): 1524-1530. DOI: https://hdl.handle. net/10652/3422

Montecinos, A., M. (2014). Free Fall Misconceptions: Results of A Graph Based Pre-Test of Sophomore Civil Engineering Students. European J of Physics Education, 5(3): 1-7.

Motlhabane, A. (2016). Learner's Alternative and Misconception in Physics: A Phenomenographic Study. Journal of Baltic Science Education, 15(4):424-440. DOI: http://journals.indexcopernicus.com/abstract.php?icid=1217755

Mulwa, E., C. (2015). Difficulties Encountered by Students in the Learning and Usage of Mathematical Terminology: A Critical Literature Review. Journal of Education and Practice, 6(13), 27-37. DOI: https://eric. ed.gov/?id=EJ1080447

Nowak, A., Z. (2016). The Contribution of Education to Economic Growth: Evidence from Nepal. International Journal of Economic Sciences, 5(2): 2241. DOI: 10.20472/ES.2016.5.2.002

Nurlaila, L., Siti, S., \& Riandi. (2018). Preliminary Studies of Analyzing Misconception and Scientific Argumentation using Diagnostic Question Clusters (DQCS) of Molecular Genetics Concept. Bio Ed UIN Jurnal Program Studi Pendidikan Biologi, 8(2): 43-53. DOI: https://doi. org/10.15575/bioeduin.v8i2.3190

Oberoi, M. (2017). Review of Literature on Student's Misconceptions in Science. IJSRE, 5(3), 6274-6280. DOI: http://dx.doi.org/10.18535/ijsre/v5i03.05

OECD. (2016). PISA Result Excellence and Equity in Education (Volume 1). Paris: OECD Publishing, from https://www.mecd.gob.es/inee/dam/jcr

Osuolale, O., J. (2014). Problems of Teaching and Learning Science in Junior Secondary Schools in Nasarawa State, Nigeria. Journal of Education and Practice, 5(34): 109-118. DOI: https://www.iiste.org/Journals/index. $\mathrm{php} / \mathrm{JEP} /$ article/view/17248 
Rusilowati, A. (2015). Pengembangan Tes Diagnostik Sebagai Alat Evaluasi Kesulitasn Belajar Fisika. Prosiding. Artikel disajikan dalam Seminar Nasional Fisika dan Pendidikan Fisika Ke-6, 6(1): 1-10. http://jurnal.fkip.uns.ac.id/ index.php/prosfis1/article/view/7684/5672

Rusiman, A., S. \& Norziha, C., H. (2017). The Use of Concret Material in Teaching and Learning Mathematics. Journal of Engineering and Applied Sciences, 12(8): 2170-2174. DOI: 10.3923/jeasci.2017.2170.2174

Samsudi. (2006). Desain Penelitian Pendidikan. Semarang: Universitas Negeri Semarang Press.

Schmidt, A., L. (2011). Creativity in Science: Tension between Perception and Practice. Creative Education, 2 (5): 435-445. DOI: $10.4236 /$ ce.2011.25063

Smith, P., S., \& E., R., Banilower. (2006). Measuring Middle Grades Students' Understanding of Force and Motion Concepts: Insight In to The Structure of Students. Proceeding. Paper Preseted at The National Association for Research in Science Teaching, Annual Meeting April 3-6 San Francisco, CA, United States.

Suparno, P. (2013). Miskonsepsi dan Perubahan Konsep dalam Pendidikan FIsika. Jakarta: Grasindo

Thompson, F. \& Logue, S. (2006). An Exploration of Common Student Misconception in Science. International Education Journal, 7(4): 553-559.

Udompong, L. \& Suwimon, W. (2014). Diagnosis of the Scientific Literacy Characteristics of Primary Students. Procedia Social and Behavioral Sciences, 116: 5091-5096. DOI: 10.1016/j.sbspro.2014.01.1079

Wulandari, E. \& Raekha, A. (2018). Menyambut PISA 2018: Pengembangan Literasi Matematika untuk Mendukung Kecakapan Abad 21. Jurnal Pendidikan Matematika, 1(1): 31-38. DOI: 10.36277/defermatv1i1.14

Yangin A., Sabri, S. \& Yasin, G. (2014). Prospective Teachers' Minconceptions about Classification of Plants and Changesin Their Misconceptions During Pre-Service Education. Journal of Baltic Science Education, 13(3): 105-117. 